\title{
Barbara Jundo-Kaliszewska, Zaktadnicy historii. Mniejszość polska w postradzieckiej Litwie, Wydawnictwo Uniwersytetu Łódzkiego, Łódź 2019, ss. 432
}

https://doi.org/10.19195/1429-4168.24.23

W marcu 2019 roku nakładem Wydawnictwa Uniwersytetu Łódzkiego ukazała się monografia Zakładnicy historii. Mniejszość polska w postradzieckiej Litwie. Autorka zaprezentowała w niej społeczność polską przełomu lat osiemdziesiątych i dziewięćdziesiątych XX wieku. Był to czas, kiedy ku upadkowi chyliło się imperium radzieckie.

Wyjaśnijmy tytuł książki. Barbara Jundo-Kaliszewska we wstępie napisała o nim:

nawiązuje bezpośrednio do prezentowanego przez elity RP na przełomie lat 80. i 90. XX w. poglądu, że sprawy tamtejszych Polaków zostaną rozwiązane w niezależnej od ZSRR i całkowicie niepodległej Litwie. Jednakże nowożytna litewska świadomość narodowa ukształtowała się w oparciu o pamięć historyczną, a co za tym idzie — o silny czynnik antypolski. W związku z tym zarówno pierwsza, jak też druga niepodległość Litwy przesiąknięte były powielaniem stereotypów, które pozostają skutecznym narzędziem konsolidacji społeczeństwa i sprawowania władzy ${ }^{1}$.

Po zakończeniu I wojny światowej pojawiły się odrodzona II Rzeczpospolita Polska oraz Republika Litewska. Niestety oba państwa miały bardzo niejednorodną strukturę etniczną i narodowościową. Większość mieszkańców województwa wileńskiego i nowogródzkiego zadeklarowała narodowość polską, która w niedługim czasie stała się zarzewiem konfliktu, czynnikiem wywołującym wzajemne nieporozumienia. W historii obu państw już wcześniej zauważalne były animozje i spory. Okazało się zatem, że „boje o nowe granice państw w Europie Środkowo-Wschodniej dopiero się rozpoczynały. Zarówno w historii Polski, jak i Litwy lata 1918-1922 naznaczyły się ostrymi starciami wojskowymi i politycznymi. Jedną z najbardziej zaciekłych walk Polacy i Litwini musieli stoczyć między sobą"2. Te wydarzenia w historii nazywane są ,,buntem Żeligowskiego”. W wyniku walk omawiane tereny zostały w 1922 roku włączone do Polski. Przez następnych kilkanaście lat właściwie nie można było mówić o jakichkolwiek stosunkach polsko-litewskich: wzajemne relacje państw były bardzo napięte i nie istniała żadna szansa na ich poprawę. Nawiązania do wspólnej historii spotykały się natomiast z nieprzychylnym odbiorem. Jedność nie mogła zaistnieć, bowiem

wspomnienia o wspólnej drodze w przeszłości, które Polacy uważali za bratnie wyciągnięcie dłoni, Litwini przyjęli jako zamach na ich życie narodowe. I oto zamiast w fazę sąsiedzkiej przyjaźni, oba narody weszły w okres konfliktów zbrojnych. [...]. Fakt ten zniszczył zaufanie do narodu polskiego. [...] Litwini nie zgodzili się na utrzymywanie normalnych stosunków dyplomatycznych z Polską. Dla narodu litewskiego była to jedyna droga do wyrażenia protestu

1 B. Jundo-Kaliszewska, Zakładnicy historii. Mniejszość polska w postradzieckiej Litwie, Łódź 2019, s. 14-15.

2 Ibidem, s. 43.

Wrocławskie Studia Wschodnie 24, 2020

(C) for this edition by CNS 
przeciwko wyrządzonej mu krzywdzie. Tak więc do roku 1938 między Polską i Litwą istniała mała ,żelazna kurtyna"3.

Do pewnej normalizacji doszło tuż przed wybuchem II wojny światowej. Jednak działania wojenne i decyzje podjęte przez dwóch agresorów (Stalina i Hitlera) zlikwidowały szansę na współpracę. Dnia 23 sierpnia 1939 roku został podpisany radziecko-niemiecki układ o nieagresji — pakt Ribbentrop-Mołotow.

Dnia 28 września 1939 roku ZSRR i Niemcy podpisały kolejne porozumienie układ o przyjaźni i granicach. Jego integralną częścią były tajne protokoły, w wyniku których dokonano ostatecznego podziału łupów w Europie Środkowo-Wschodniej. Wówczas zaczął się kolejny etap trudnej historii: na kilkadziesiąt lat Litwa została włączona do ZSRR.

Autorka swoje rozważania ograniczyła do terenu współczesnej Wileńszczyzny. Była to przemyślana decyzja, albowiem mieszkańcy tego terenu uczestniczyli w procesie powołania polskiej autonomii, a zamieszkiwany przez nich obszar w wyniku działań wojennych znalazł się w Litewskiej Socjalistycznej Republice Radzieckiej, a następnie w Republice Litewskiej. W bardzo odważny, klarowny i umiejętny sposób odpowiedziała na szereg trudnych pytań, z którymi postanowiła zmierzyć się w swojej pracy. Doskonała znajomość tematu pozwoliła jej zmierzyć się z zadaniem i udzielić odpowiedzi na nurtujące zagadnienia:

czy oddolne inicjatywy społeczności polskiej na przełomie lat 80 . i 90 . XX w. były inspirowane przez służby specjalne ZSRR? W jaki sposób Związek Radziecki w okresie przebudowy wykorzystał wzajemne animozje i resentymenty Litwinów i Polaków zamieszkujących Litwę? Czy wileńscy Polacy byli werbowani i działali w omawianym okresie na rzecz KGB? Jak w praktyce wykorzystywano tzw. polskij wopros i inne radzieckie mechanizmy manipulacji? ${ }^{4}$

Koniec XX wieku to czas, kiedy w LSRR w wyniku wydarzeń politycznych powstała silna i niezależna mniejszość polska. Jundo-Kaliszewska zaprezentowała jej poglądy, opinie, strukturę i rolę, jaką odegrała w omawianym czasie. W interesujący i niezwykle ciekawy sposób przedstawiła zarzewie konfliktu polsko-litewskiego oraz zaszłości historyczne, a także nakreśliła rolę Polski w autonomicznych aspiracjach mniejszości oraz wpływ radzieckich służb specjalnych na wydarzenia w ówczesnym państwie litewskim. Druga połowa lat osiemdziesiątych XX wieku w Europie Środkowo-Wschodniej to czas kształtowania się ruchów narodowych. Do historii przeszły pod nazwą Jesieni Ludów (Jesieni Narodów). W dniu 11 marca 1985 roku sekretarzem generalnym KC KPZR został Michaił Sergiejewicz Gorbaczow. Katalizatorem nowej polityki ZSRR stała się przebudowa (pieriestrojka), która jednocześnie zaaktywizowała narody i obudziła w nich nadzieję na zmianę. Efektem tego procesu był rozpad ZSRR, aspekty narodowościowe zaś doprowadziły do demontażu polityki republik związkowych pozostających w dotychczasowych strukturach monolitu radzieckiego. Podłożem konfliktu polsko-litewskiego były kwestie dotyczące

3 J. Girnius, W poszukiwaniu dialogu polsko-litewskiego, [w:] W poszukiwaniu innej historii. Antologia tekstów opublikowanych na łamach periodyków Instytutu Literackiego w Paryżu, red. S. Stobiecki, S.M. Nowinowski, współp. A. Brzezińska, M. Przybysz, Łódź-Paryż 2015, s. 556.

${ }^{4}$ B. Jundo-Kaliszewska, op. cit., s. 15.

Wrocławskie Studia Wschodnie 24, 2020

(C) for this edition by CNS 
sporu historycznego o „przeszłość” oraz języka ojczystego (polskiego). Problem „dwujęzyczności" na obszarze ZSRR był przedmiotem obrad plenum KC KPZRR w lutym 1988 roku. Temat trafił na bardzo podatny grunt — w końcu zdecydowaną większość obszaru Wileńszczyzny zamieszkiwała mniejszość polska. Piątego maja 1988 roku powstało Stowarzyszenie Społeczno-Kulturalne Polaków na Litwie, później przekształcone w Związek Polaków na Litwie. To wydarzenie miało miejsce na I Zjeździe Stowarzyszenia w dniach 15-16 kwietnia 1989 roku w Wilnie; natomiast 3 czerwca 1988 roku powołano Litewski Ruch na Rzecz Przebudowy Sajūdis. Ewolucja poglądów i wydarzenia polityczne spowodowały, że jego przewodnim hasłem stało utworzenie samodzielnego i niezależnego państwa litewskiego. W procesie, który doprowadził do zmian i litewskiej niepodległości, rolę odegrała też „śpiewająca rewolucja” — akcja muzyczna propagująca swobody obywatelskie. Pod koniec lipca 1988 roku zorganizowano Roko maršas (Rockowy Marsz), na którym śpiewano pieśni rockowe krytykujące rządzących, wygłaszano przemówienia patriotyczne, prezentowano symbole narodowe oraz zbierano środki na rzecz Sajūdisu. Jundo-Kaliszewska wskazała, że również

Polacy na Litwie przeżywali własną odsłonę ,śsiewającej rewolucji”. Masowo tworzyły się polskie zespoły ludowe, organizowano koncerty. Powstawały nowe pieśni patriotyczne, w tym Wileńszczyzny drogi kraj (autor J. Mincewicz). Lato roku 1989 naznaczyło się wieloma inicjatywami środowisk polskich: 23 czerwca w miasteczku Bolosza z inicjatywy ZPL odbył się I Turystyczny Zlot Polaków na Litwie, w trakcie którego dominowała polska symbolika narodowa, śpiewano polskie pieśni patriotyczne, a występujący na nim działacze odwoływali się do sentymentów narodowych i coraz odważniej mówili o powołaniu polskiej autonomii. W lipcu 1989 r. służby KGB zanotowały, że w imprezach i uroczystościach organizowanych przez ZPL licznie uczestniczą obywatele PRL, którzy przyjeżdżają na Litwę prywatnie 5 .

Wszelkie działania i ruchy były bacznie obserwowane przez Litwinów, którzy bardzo źle znosili i odbierali inicjatywy samodzielności. Doskonale pamiętali wydarzenia z dwudziestolecia międzywojennego oraz inicjatywy niezależności. Podjęte działania i dążenia wolnościowe w LSRR zmierzały już tylko w jednym kierunku. Konsekwencją wydarzeń i zmian, jakie miały miejsce w latach 1988-1990, było ogłoszenie przez Litwę niepodległości. Miejmy na uwadze, że „przyszłość którą chcemy budować musi dać wolność każdemu na swej ziemi, musi dać każdemu równe prawa do wszystkiego co kocha, a przede wszystkim do kolebki jego przeszłości historycznej”6.

Akt restytucji niepodległego państwa litewskiego został ogłoszony 11 marca 1990 roku. Przywrócono pierwotną nazwę państwa - Republika Litewska, i symbole narodowe. Niestety ani strona radziecka, ani żadne z państw zachodnich nie uznały nowego państwa. Żmudne rozmowy trwały wiele miesięcy; w końcu jednak 26 kwietnia 1994 roku został podpisany traktat o przyjaźni i dobrosąsiedzkiej współpracy między Polską i Litwą.

Ogromna praca badawcza jest doskonale widoczna w imponującej bibliografii (s. 401-431), którą autorka podzieliła na: archiwalia, dokumenty publikowane, źródła

5 Ibidem, s. 143.

6 J. Iwanowski, Dialog polsko-litewski, [w:] W poszukiwaniu innej historii..., s. 564.

Wrocławskie Studia Wschodnie 24, 2020

(C) for this edition by CNS 
internetowe, portale internetowe, opracowania, czasopisma i prasę. Kwerenda dokumentów radzieckich służb specjalnych pozwoliła odpowiedzieć na pytania, które nurtują nie tylko zawodowych historyków, politologów, dziennikarzy, lecz także wszystkich zainteresowanych tą niezwykle ciekawą tematyką. Na kartach książki zostały szczegółowo odnotowane przebieg zdarzeń historycznych, daty dzienne, nazwiska i instytucje. Publikacja stanowi wysokiej jakości materiał, który powinien być lekturą obowiązkową w badaniach dotyczących relacji polsko-litewskich. Doskonale prezentuje i zaznajamia czytelnika z losami mniejszości polskiej na Wileńszczyźnie.

Książka została podzielona na trzy rozdziały oraz wstęp i zakończenie. Zawarto w niej wykaz najważniejszych skrótów oraz bardzo pomocny wybór toponimii (nazwy miejsc). Pojawienie się tej pracy na rynku wydawniczym z pewnością przybliży czytelnikom historię Polaków na Litwie, a także pozwoli im spojrzeć na dzieje i historię mniejszości polskiej z nowej perspektywy. Nie ulega wątpliwości, że lektura ta będzie budzić wiele emocji i skrajnych opinii.

Monografia powstała na podstawie rozprawy doktorskiej zatytułowanej Mniejszość polska w niepodległej Litwie, obronionej w 2016 roku w Instytucie Historii Uniwersytetu Łódzkiego pod kierunkiem prof. nadzw. dr. hab. Albina Głowackiego. Barbara JundoKaliszewska jest absolwentką Uniwersytetu Łódzkiego, doktorem nauk humanistycznych z zakresu historii. Urodziła się w polskiej rodzinie na terytorium LSRR. Pochodzi z Ejszyszek (rejon solecznicki), z mniejszości polskiej. Od 1999 roku mieszka w Polsce. Zawodowo swoje losy związała z macierzystą uczelnią. W godny podziwu i warty naśladowania sposób pielęgnuje swoją miłość do wartości rodzinnych oraz miejsca swojego pochodzenia.

Lilianna Światek

ORCID: 0000-0001-8735-2655 